\title{
Red propolis as an additive for preweaned dairy calves: Effect on growth performance, health, and selected blood parameters
}

\author{
G. S. Slanzon, A. F. Toledo, A. P. Silva, M. G. Coelho, M. D. da Silva, A. M. Cezar, and C. M. M. Bittar*† \\ Department of Animal Science, "Luiz de Queiroz" College of Agriculture, University of São Paulo, Piracicaba, SP 13418-900, Brazil
}

\begin{abstract}
Propolis is a natural product produced by bees and sold commercially. It is well known for its antioxidant and anti-inflammatory effects and the ability to improve immune system functions in humans and animals. Many of its positive effects can contribute positively to animal productivity. The aim of this study was to evaluate possible beneficial effects of red propolis supplementation on growth performance, metabolism, and health status of dairy calves during the preweaning phase. Thirty-two newborn calves were individually housed, with free access to water and concentrate, and fed $6 \mathrm{~L} / \mathrm{d}$ of whole milk. Animals were distributed in 2 treatments: (1) control and (2) supplementation with $4 \mathrm{~mL} / \mathrm{d}$ of red propolis ethanolic extract (30\%; EEP) in whole milk. Feed consumption and fecal and health scores were monitored daily from $1 \mathrm{~d}$ of age to $56 \mathrm{~d}$. Calves were weighed and measured weekly. Blood samples were collected weekly, $2 \mathrm{~h}$ after morning milk feeding, for determination of glucose, total serum protein, urea, lactate, $\beta$-hydroxybutyrate, total iron binding capacity, and total leukocytes (white blood cells) and erythrocytes (red blood cells). Starter feed intake, daily weight gain, and body measurements were not affected by the EEP supplementation. Blood parameters were also not affected, with the exception for the red blood cell counts, which were lower in animals supplemented with EEP. Supplementation with EEP significantly decreased fecal score, days with diarrhea, and veterinary treatments of diarrhea. These results indicate that red propolis supplementation has potential to improve calf health and reduce the incidence of diarrhea and, as a
\end{abstract}

Received March 18, 2019.

Accepted June 29, 2019.

*Corresponding author: carlabittar@usp.br

$\dagger$ Current address for all authors: Escola Superior de Agricultura "Luiz de Queiroz" (ESALQ), Av. Pádua Dias 11, Piracicaba, São Paulo, CEP 13418-900, Brazil. consequence, the use of antibiotics in calf rearing systems.

Key words: dairy calf, health, propolis, diarrhea

\section{INTRODUCTION}

In intensive systems, calves are replaced continuously, and this production pattern leads to high risk of infection. In this practice antibiotics are considered an important tool to raise calves, reducing the morbidity and mortality due to diseases such as diarrhea, septicemia, and respiratory diseases (Constable, 2003). However, public concern about the routine use of these drugs in animal production is increasing due to the development of bacteria resistant to antibiotics (Teuber, 2001). According to Tikosfsky et al. (2003), if the use of antimicrobials is the main reason for the selective pressure that promotes the resistance development, then reducing its use in production systems would consequently decrease this problem.

Propolis is a complex mixture, formed by resinous and balsamic material, with a complex and variable composition related to the flora of each region visited by the bees and the period of resin collection (Ghisalberti, 1979). Propolis may represent a potential natural additive to control diseases and act preventively in animals, promoting their immunity. Studies indicate that the antibacterial activity of propolis controls the agent of the disease without developing resistance (Mot et al., 2014). Dairy calves are exposed to several pathogens, and if their immune system is not sufficiently strengthened, the disease incidence can be high. Specific functions of the immune system are responsible for carrying out the defense actions.

Yucel et al. (2015) reported the beneficial effect of propolis tincture $(2 \mathrm{~mL} / \mathrm{d})$ on the prevention of diarrhea in calves, which consequently affected their performance in a positive way. However, no research has investigated the effects of red propolis on the metabolism, development, and health of dairy calves. We specifically studied red propolis because of its strong biological action due to its chemical composition rich 
in isoflavonoids, different from other types of propolis (Alencar et al., 2007). Red propolis was recently found in the Brazilian northeast coast region in an Alagoas mangrove (Alencar et al., 2007). Its botanical origin is the plant Dalbergia ecastaphyllum, a species of legume rich in flavonoids (Silva et al., 2008). Previous studies have shown that red propolis has a high antimicrobial activity against gram-positive bacteria and limited activity against gram-negative strains (Sforcin et al., 2000).

Propolis has been shown to treat numerous diseases, in human and veterinary medicine, and has had positive effects on animal health (Kadhim et al., 2018). Because of the high occurrence of gastrointestinal disorders and their effect on calf morbidity and mortality, dairy systems have increased the inclusion of additives that have a positive effect on the control of diarrhea. Because of its antimicrobial, anti-inflammatory, antioxidant, antiviral, and immunomodulatory properties (Alencar et al., 2007), propolis has a high potential to be used in dairy systems as an additive, improving animal health and performance. We hypothesized that red propolis supplementation would provide beneficial effects on growth performance, metabolism, and health status of dairy calves during the preweaning phase.

\section{MATERIALS AND METHODS}

\section{Preparation and Analysis of the Propolis Extract}

Ethanolic extract of propolis (EEP) was prepared using the crude red propolis produced by bees (Apis mellifera) from the plant Dalbergia ecastaphyllum, a typical vegetation of the mangroves of the State of Alagoas. The extraction of propolis was done according to Alencar et al. (2007) for a final concentration of $30 \%$ of red propolis. The analysis of the EEP samples used for the study was carried out at the Department of Agrifood, Food and Nutrition, "Luiz de Queiroz" College of Agriculture, University of São Paulo, Piracicaba, Brazil. The HPLC chromatogram of the EEP was obtained by the HPLC method as described by Bueno-Silva et al. (2017).

\section{Animals, Housing, and Management}

All procedures with animals were in accordance with the ethical standards of the University of Sao Paulo and federal laws and were approved by the Institutional Animal Care and Use Committee (protocol number 2017.5.1122.11.3). Thirty-two Holstein calves (14 heifers and 18 bulls) born at the herd of the Animal Science Department of the "Luiz de Queiroz" College of Agri- culture, Piracicaba, São Paulo, Brazil, were enrolled in this study. As the calves were born in March to August 2017, they were transferred to the experimental calf unit of the university until 32 calves had been enrolled in the study. During this period, the average temperature was $24^{\circ} \mathrm{C}$, with maximum of $32.1^{\circ} \mathrm{C}$ and minimum of $5.1^{\circ} \mathrm{C}$. The mean relative humidity during the study period was $76 \%$, and the average rainfall was $89.5 \mathrm{~mm} /$ mo.

Animals were blocked according to their date of birth, weight, and sex and distributed randomly into 1 of 2 treatments: (1) control and (2) supplementation with 4 $\mathrm{mL} / \mathrm{d}$ of EEP in whole milk, starting on the third day of age. Calves were separated from their dam at birth, weighed $(35.5 \pm 1.2 \mathrm{~kg})$, and fed $4 \mathrm{~L}$ of colostrum in 2 feedings by bottle within $6 \mathrm{~h}$ of birth. The colostrum quality was measured using a colostrometer, and only high quality colostrum ( $>60 \mathrm{mg} / \mathrm{L}$ of $\mathrm{IgG})$ was fed to the calves. When fresh colostrum was not adequate in quality or volume, frozen stored colostrum was thawed for the newborn. A blood sample was collected from the jugular vein $48 \mathrm{~h}$ after the first feeding of colostrum, and the serum was analyzed using a refractometer (Deelen et al., 2014). There were no differences $(P>$ 0.05 ) between groups for passive immune transfer, with average and standard deviation for total serum protein of $5.98 \pm 0.91$ and $5.61 \pm 0.96$ for calves in control and supplemented groups, respectively. Four calves of each group $(25 \%)$ presented total serum protein $<5.5 \mathrm{mg} /$ $\mathrm{dL}$, a cut-point to consider failure of passive immune transfer.

Calves were bucket fed (no teat) $6 \mathrm{~L} / \mathrm{d}$ of whole milk in 2 meals (0700 and $1700 \mathrm{~h}$ ). Calves had free access to water and ground solid feed (Ração Bezerra AgMilk Agroceres Multimix Nutrição Animal Ltda., Rio Claro, SP, Brazil), with orts measured to calculate daily intake. After refusals were weighed, feeding was calculated considering the previous day's intake, with an increase of at least $150 \mathrm{~g}$. Starter delivery was done just after morning milk feeding, and it was available until the next day. Samples of starter concentrate were taken biweekly for analysis. The DM content was measured by drying at $100^{\circ} \mathrm{C}$ in a forced-air oven for $24 \mathrm{~h}$ (AOAC International, 2002; method 925.40); ash by furnace incineration at $600^{\circ} \mathrm{C}$ (AOAC International, 2002; method 942.05); ether extract using petroleum ether (AOAC International, 2002; method 920.39); CP according to the Dumas method (Wiles et al., 1998), with an N analyzer (FP-528; LECO, St. Joseph, MI); and free-ash NDF according to Van Soest et al. (1991), using sodium sulfite and thermo-stable amylase. Values of TDN were calculated by the equations proposed by Weiss (1993) and NFC according to the equation NFC 
$=100-(\mathrm{CP}+$ ether extract $+\mathrm{NDF} c p+$ ash $)$, where NDFcp was NDF free of CP. Milk samples were taken weekly and analyzed for fat, protein, and lactose by Fourier transform infrared spectroscopy (Lefier et al., 1996) and for SCC by flow cytometry (Clínica do Leite, Piracicaba, Brazil).

Calves were housed in individual shelters $(1.35 \mathrm{~m}$ in height, $1 \mathrm{~m}$ in width, and $1.45 \mathrm{~m}$ in depth) and contained with a chain belt attached to a thin chain, allowing an adequate walking area but with no physical contact with other animals. Shelters were distributed in a trimmed, grassy field.

Animals were weighed weekly in a mechanical scale before the morning milk feeding until the eighth week of life. To calculate the number of days with fever, body temperature was recorded daily from d 1 until 56 $\mathrm{d}$ of age after the morning milk feeding. Blood samples were collected weekly, always $2 \mathrm{~h}$ after the morning feeding, through jugular venipuncture into vacuum tubes containing sodium fluoride and potassium EDTA (Vacuette of Brazil, Campinas, SP, Brazil). Samples were centrifuged (Universal 320R, Hettich, Tuttlinger, Germany) at $2,000 \times g$ for $20 \mathrm{~min}$ at $4^{\circ} \mathrm{C}$, and plasma or serum were freezer stored $\left(-26^{\circ} \mathrm{C}\right)$ until subsequent analysis. Specific commercial enzymatic kits (Labtest Diagnóstica S.A., Lagoa Santa, MG, Brazil) were used to analyze plasma glucose (Ref.: 85), total serum protein (Ref.: 99), plasma urea (Ref.: 104), lactate (Ref.: 116), and total iron binding capacity (Ref.: 41), using the Automatic System for Biochemistry-SBA Model 200 (CELM, Barueri, SP, Brazil). The determination of BHB was performed using a Ranbut enzyme kit-Ref.: RB1007 (Randox Laboratories-Life Sciences Ltd., Crumlin, UK, imported by Randox Brasil Ltda., São Paulo, SP, Brazil) using the Automatic System for Biochemistry-Model SBA-200 (CELM).

\section{Fecal Score and Diarrhea Treatment}

Fecal score was monitored daily as described by Larson et al. (1977) regarding the fluidity of feces: $1=$ normal and firm; $2=$ loose but with general healthy aspect; $3=$ very loose, no watery separation; and $4=$ watery. Fecal scores $\geq 3$ were considered diarrhea when they occurred for 2 or more consecutive days. Oral rehydration solution $(2 \mathrm{~L} / \mathrm{d}$, independent on the severity of diarrhea) was provided, between milk feedings, when the fecal score was $\geq 3$ until the score was $\leq 2$.

Animal health was recorded daily, as well as diagnoses, interventions, and administration of antimicrobials. Antibiotic therapy was administered only when the animal presented fever and symptoms of depression, such as refusal of the liquid diet and recumbency, as directed by a veterinarian.

\section{Blood Cell Count}

An aliquot of blood was taken from the tube containing anticoagulant for the count of total erythrocytes (red blood cells; RBC). Briefly, $20 \mu \mathrm{L}$ of the blood sample was diluted in $4 \mathrm{~mL}$ in Gower solution (12.5 $\mathrm{g}$ of sodium sulfate and $33.3 \mathrm{~mL}$ of glacial acetic acid in $100 \mathrm{~mL}$ of distilled water). A small amount of this diluted sample was pipetted into the side opening of the mirrored Neubauer chamber and observed through a microscope (400X, Bioval, PR, Brazil). The counts were made in 5 smaller quadrants located in the center of the marked area of the Neubauer chamber, and the amount of erythrocytes per microliter was determined by the following equation: erythrocytes $/ \mu \mathrm{L}=\Sigma q \times 5$ $\times 10 \times 200$, where $\Sigma q=$ sum of the erythrocyte count of 5 quadrants of the Neubauer chamber, $5=$ chamber area, $10=$ chamber height, and $200=$ dilution factor.

For the determination of the total white blood cell count (WBC), $20 \mu \mathrm{L}$ of the blood sample was diluted in $0.4 \mathrm{~mL}$ of Turk fluid $(2 \mathrm{~mL}$ of acetic acid, $1 \mathrm{~mL}$ of gentian violet, $100 \mathrm{~mL}$ of distilled water), pipetted into the Neubauer chamber, and observed under a microscope $(400 \times$, Bioval). The counts were made in the 4 quadrants located at the ends of the marked area of the Neubauer chamber, and the number of leukocytes per microliter was determined by the following equation: leukocytes $/ \mu \mathrm{L}=(\Sigma q / 4) \times 10 \times 20$, where $\Sigma q=$ sum of the leukocyte count of the 4 quadrants at the end of the Neubauer chamber, $4=$ chamber squares, $10=$ chamber height, and $20=$ dilution factor.

\section{Statistical Analysis}

Sample size calculations using a power of $90 \%$ and a significance level of 0.05 (R Core Team, 2015) indicate that a difference in most of the parameters would be evident with 16 calves per group (control vs. EEP). The experimental design was a randomized block design, and animals were allocated to the blocks according to their birth weight, date of birth, and sex. The performance data, blood metabolites, cell count, besides fecal score, days with diarrhea, and days with fever were analyzed as time-repeated measures using the MIXED procedure of the SAS statistical package (version 5.0, SAS Institute Inc., Cary, NC) for mixed models, with weeks as repeated measures (model [1]). Among the 15 different covariance structures tested, the one that best fit the statistical model was chosen based on the lowest value of Akaike's information criterion corrected (Wang and Goonewardene, 2004). With the exception of BHB, $\mathrm{RBC}$, and total serum protein, which were analyzed using the Toeplitz covariate, all parameters were analyzed using ARh (heterogeneous autoregressive) covari- 
ate. The model included as fixed effects the effects of treatment, week (age of animals), and the interaction of treatment and week. The block effect was included in the model as a random effect. For data that were pooled to create a single measure, such as veterinary treatments per calf, PROC MIXED of the statistical package SAS (version 5.0, SAS Institute Inc.) was used according to model [2]. The model included treatment as a fixed effect and block as a random effect.

$$
Y_{i j k}=\mu+T_{i}+B_{j}+S_{k}+T S_{i k}+E_{i j k},
$$

where $Y_{i j k}=$ response variable; $\mu=$ general mean; $T_{i}=$ treatment effect (propolis supplementation); $B_{j}=$ block effect; $S_{k}=$ age effect of animals (week of data collection per sample); $T S_{i k}=$ interaction between treatment effect and age; and $E_{i j k}=$ effect due to chance (residual).

$$
Y_{i j}=\mu+T_{i}+B_{j}+E_{i j},
$$

where $Y_{i j}=$ response variable; $\mu=$ general mean; $T_{i}=$ treatment effect (propolis supplementation); $B_{j}=$ block effect; and $E_{i j}=$ effect due to chance (residual).

\section{RESULTS AND DISCUSSION}

\section{Propolis Composition}

Red propolis has a complex chemical composition, with more than 300 compounds being reported when analyzed in different ways (Rufatto et al., 2017). Through chromatography, obtained by the HPLC method, it was possible to verify that the compounds daidzein, vestitol, neovestitol, biochanin A, and formononetin were present in the EEP (data not presented). Our findings agree with Alencar et al. (2007), who found the same compounds.

\section{Calf Growth and Performance}

Starter concentrate presented $86.2 \%$ DM, $7.9 \%$ ash, $23.4 \% \mathrm{CP}, 3.6 \%$ ether extract, $16.3 \% \mathrm{NDF}$, and $78.6 \%$ DM of TDN. Chemical composition was adequate for dairy calves during the milk-feeding period.

On average, milk contained $12.5 \%$ solids, $3.78 \%$ fat, and $3.34 \%$ protein and had an SCC of $429 \pm 106 \times 10^{3}$ cells/mL. Milk SCC may be considered high, according to international standards; however, it is still below averages found in Brazil, mainly during the summer (Busanello et al., 2017). Microbiological milk quality is one of the factors associated with diarrhea occurrence and may have predisposed calves to the disease during the trial. However, because the milk was fed for both treatment groups, the challenge occurred for both supplemented and not-supplemented calves.

Milk intake was not affected by propolis supplementation and remained constant throughout the study. Despite the bitter flavor of the EEP, which is very strong in most cases, the calves did not reject the milk in which the EEP was mixed. Starter intake increased with animal age because of the increase in their nutritional requirements, as observed by others with calves raised in similar management and environmental conditions, when liquid diet volume was constant (Bittar et al., 2016; de Paula et al., 2017). Starter feed intake, BW, and daily weight gain were not affected by EEP supplementation $(P>0.05$, Table 1$)$. The same finding was observed for Santa Inês ewes by Morsy et al. (2016), who found that mean values of BW and BCS were not significantly $(P>0.05)$ affected by Brazilian red propolis compared with the control group. Animal age had a significant effect on those variables $(P<$ $0.0001)$, but none of them were affect by the interaction of EEP supplementation and age $(P>0.05)$. Greater BW and ADG were expect for supplemented calves, especially during the first weeks of life, when animals present more frequent occurrences of diarrhea (Figure 1), which may compromise feed intake and performance. Additives can cause positive results in growth performance as an indirect effect of balancing microbiota with a consequent lower prevalence of pathogens and greater nutrient utilization (Timmerman et al., 2005). Kupczyński et al. (2012) supplemented calves with EEP (4 mL/d containing 10\% of propolis) together with the milk replacer and observed lower BW in control calves, due to more diarrhea symptoms in these calves.

Yaghoubi et al. (2008) observed that animals supplemented with high doses of flavonoids extracted from propolis $\left(3.6 \times 10^{-3} \mathrm{~g} / \mathrm{kg}\right.$ of BW $)$ had greater BW during the fifth week of life and achieved greater starter intake at younger ages when compared with calves supplemented with lower doses of flavonoids or not supplemented at all. Stradiotti et al. (2004) reported in vitro effects of propolis similar to ionophores, with the ability to perform ruminal manipulation and increase feed efficiency. Apparently, propolis supplementation through solid diet has more effects on feed intake than liquid dietary supplementation, due to its effects on the ruminal microbial population. Indeed, Zawadzki et al. (2011) concluded that the addition of propolis extract, containing $0.054 \mathrm{mg} / \mathrm{g}$ of total flavonoids, to the diet of feedlot-finished Nellore bulls increased BW $(P<0.03)$ and improved feed conversions compared with a sodium monensin-supplemented treatment. 
Table 1. Feed intake and performance of calves supplemented or not with red propolis extract

\begin{tabular}{|c|c|c|c|c|c|c|}
\hline \multirow[b]{2}{*}{ Item } & \multicolumn{2}{|c|}{ Treatment } & \multirow[b]{2}{*}{ SEM } & \multicolumn{3}{|c|}{$P$-value ${ }^{2}$} \\
\hline & Control & Propolis $^{1}$ & & $\mathrm{~T}$ & A & $\mathrm{T} \times \mathrm{A}$ \\
\hline \multicolumn{7}{|l|}{ Feed intake } \\
\hline Milk, L/d & 6.0 & 6.0 & 0.01 & 0.9207 & $<0.0001$ & 0.999 \\
\hline Starter, $\mathrm{g} / \mathrm{d}$ & 259.6 & 245.7 & 36.62 & 0.7909 & $<0.0001$ & 0.501 \\
\hline \multicolumn{7}{|l|}{$\mathrm{BW}, \mathrm{kg}$} \\
\hline Initial & 35.8 & 35.1 & 1.20 & 0.9999 & - & - \\
\hline Final & 72.5 & 73.6 & 1.64 & 0.9999 & - & - \\
\hline Average of total period & 51.6 & 51.4 & 1.12 & 0.8875 & $<0.0001$ & 0.3496 \\
\hline Weight gain, g/d & 654.5 & 694.2 & 23.47 & 0.1756 & $<0.0001$ & 0.2685 \\
\hline \multicolumn{7}{|l|}{ Body measures, cm } \\
\hline Withers height & 81.2 & 81.6 & 0.66 & 0.4154 & $<0.0001$ & 0.1169 \\
\hline Heart girth & 86.2 & 86.7 & 0.81 & 0.2857 & $<0.0001$ & 0.195 \\
\hline Hip width & 22.2 & 22.1 & 0.24 & 0.7738 & $<0.0001$ & 0.068 \\
\hline
\end{tabular}

${ }^{1}$ Propolis $=4 \mathrm{~mL} / \mathrm{d}$ of ethanolic extract of red propolis $(30 \%)$ fed with the liquid diet.

${ }^{2} \mathrm{~T}=$ treatment effect; $\mathrm{A}=$ age effect; $\mathrm{T} \times \mathrm{A}=$ treatment $\times$ age interaction.

\section{Fecal Score and Disease Occurrence}

Calves that were supplemented with EEP had lower fecal scores, fewer days with diarrhea, and fewer veterinary treatments (Table 2, Figure 1). Fecal scores were lower in calves supplemented with EEP likely because of its antimicrobial activity (Yucel et al., 2015). Although the mean fecal score did not characterize diarrhea, the supplementation was efficient in reducing the fluidity of feces during the experimental period (Table 2). In the present study, diarrhea was diagnosed when the animal presented fecal scores $\geq 3$ for 2 or more consecutive days. Diarrhea is the main disease affecting calves during the first weeks of life, and calves presented a greater fecal score during the first $3 \mathrm{wk}$ of age, regardless of the treatment. After this period, fecal scores were significantly decreased $(P<0.0001$, Figure 1$)$. During the summer, increases in temperature and humidity aid the growth of pathogens in the environment. Besides that, feeding low quality milk, such as that with a high SCC, also predisposes animals to increased occurrences of diarrhea (Roy, 1980), mainly during the first weeks of age, when colostral immunity is decreasing.

Yucel et al. (2015) found similar results, decreasing diarrhea occurrence, when they supplemented calves with $2 \mathrm{~mL} / \mathrm{d}$ of Pinus spp. propolis (common in Turkey). Kupczyński et al. (2012) also reported positive results supplementing $4 \mathrm{~mL} / \mathrm{d}$ of EEP containing $10 \%$ of propolis mixed in the milk replacer, with supplemented calves showing better health conditions and hydration score.

The highest number of days affected by the disease observed for nonsupplemented calves (Table 2), corroborated by the highest fecal score (Figure 1), occurred especially during wk 2 and 3 of life. It is common to observe an increase in diarrhea occurrence during this age supposedly because of colostrum immunity reduction (Hulbert and Moisá, 2016). The ideal dose and the number of days that propolis should be given to animals are still unknown; however, a possible explanation for the decrease in fecal score is its potent antibacterial activity (Bastos et al., 2008), responsible for decreasing the activity of the pathogens.

Because rehydration was linked to diarrhea diagnosis, oral hydration solutions were given more frequently to animals from the control group (data not presented) because of a greater incidence of diarrhea. More time, management, and labor is required to care for calves with diarrhea, resulting in greater costs and lower animal performance.

Independent of identification of the pathological agent causing diarrhea, EEP proved to be efficient during the experimental period. Because diarrhea may have several microbiological origins, several authors have reported wide activity of propolis. Ugur et al. (2000) reported the effectiveness of propolis in controlling infections caused by Escherichia coli resistant to several antibiotics. Cueto et al. (2011) studied the antiviral effect of 2 extracts of Brazilian propolis, and both presented antiviral activity against bovine viral diarrhea virus. Orsi et al. (2005) studied the antibiotic activity of Brazilian propolis on Salmonella Enteritidis and Salmonella Typhimurium and concluded that propolis has activity against gram-negative bacteria because the percentage of bacterial survival decreased with the incubation time in the propolis extract.

Despite the broad activity of propolis, the EEP supplementation had no effect in the treatments for pneumonia (Table 2). Although the number of occurrences was low, it was expected that animals supplemented with EEP would have fewer incidence of pneumonia. During the first 3 wk of life, maternal antibodies from 
$\square$ Control $\square$ Propolis
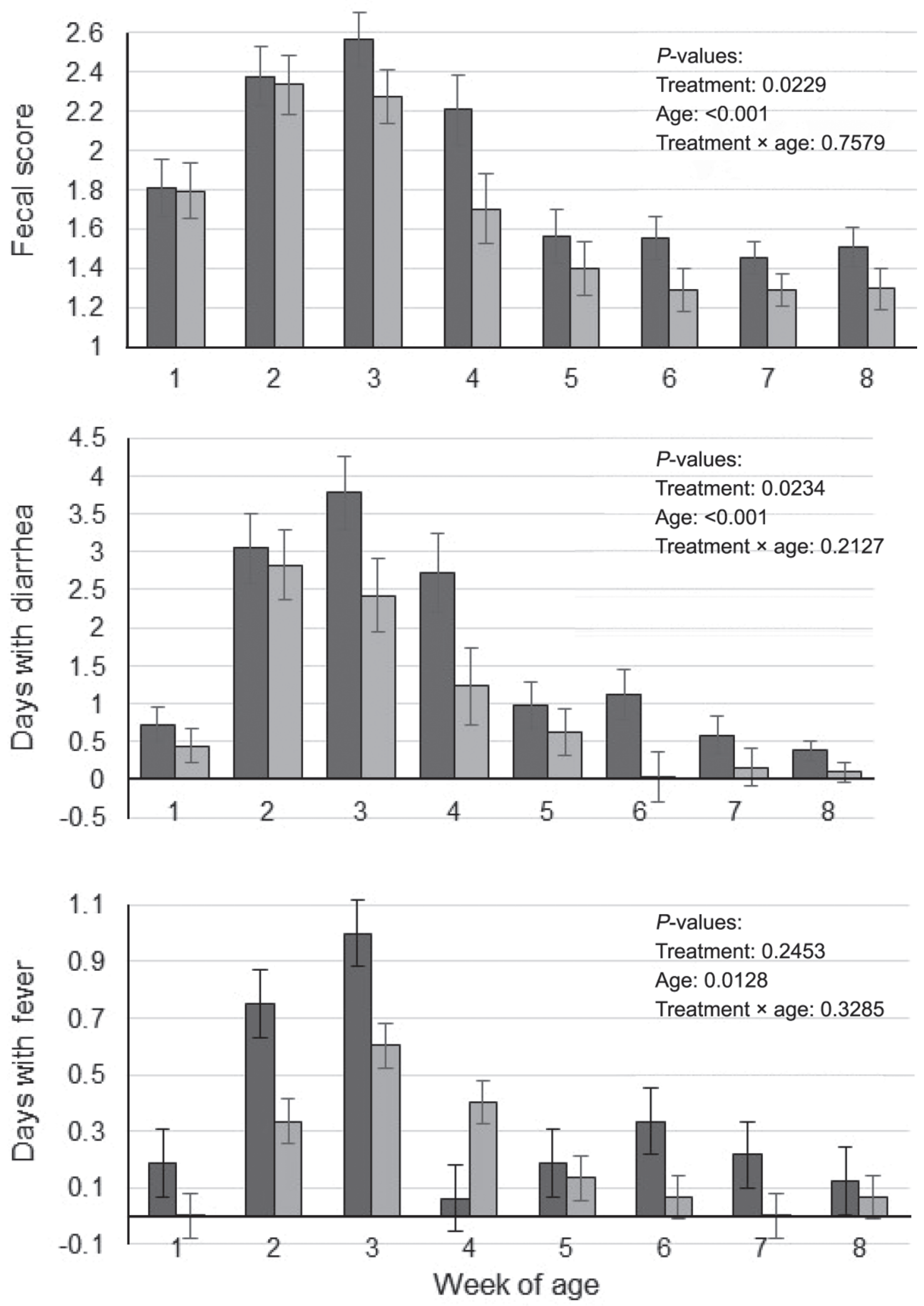

Figure 1. Fecal score $(1=$ normal and firm to $4=$ watery $)$, days with diarrhea, and days with fever of calves supplement or not with red propolis extract $[4 \mathrm{~mL} / \mathrm{d}$ of ethanolic extract of red propolis (30\%) fed with the liquid diet]. Error bars indicate SEM. 
colostrum remain in circulation, and after exposure to new microorganisms, the calf begins to develop its own defense system (Hulbert and Moisá, 2016). The calf has a greater risk of enteric disease during the first weeks of life (Svensson et al., 2003); however, from the fourth week of life, the risk of having respiratory diseases increases progressively (Hulbert and Moisá, 2016). Calves that showed clinical signs of diarrhea, such as fluid feces, lack of appetite, dehydration, and increased body temperature, were given the recommended treatment for disease with antibiotics.

Calves not supplemented with EEP were treated more often with antibiotics for diarrhea than calves supplemented with EEP (Table 2). The decrease in the number of treatments for animals supplemented with EEP affects not only animal health per se but also public health, reducing the development of bacterial resistance. Other positive results from propolis supplementation are the reduction in medical costs and required labor and fewer interventions for veterinary medication, which often threaten animal welfare.

\section{Blood Parameters}

Nutritional changes that occur with age and metabolic shift from the preruminant to ruminant condition in dairy calves are also associated with dynamic changes in blood parameters (Mohri et al., 2007). The age $\times$ treatment interaction affected $(P=0.012)$ glucose concentration. Supplemented calves had greater plasma glucose concentrations at the fourth week of life (Figure 2).

This result may be related to the lower fecal score and the fewer days with diarrhea during that week of life, allowing greater absorption of glucose. The loss of fluid that occurs during the occurrence of diarrhea is a result of increased permeability and intestinal motility, which will reduce the absorption of nutrients, fluids, and electrolytes (Naylor, 1999).
However, Kupczyński et al. (2012) observed a significant drop in plasma glucose level in calves supplement with $4 \mathrm{~mL} / \mathrm{d}$ of propolis, which were healthier and heavier than those in the control group, suggesting that they were more mature with regard to rumen development. Although the effect was not significant, EEP-supplemented calves also presented greater weight gain during the fourth week of life, corroborating with the increase in plasma glucose. Concentrations of BHB suggest the metabolism shift from the preruminant to functional-ruminant stage because they increased during the milk-feeding period $(P<0.04$, Table 3$)$. However, supplementation of EEP through a liquid diet seems to not affect rumen development. Even though an age $\times$ treatment interaction effect existed for BHB, which is a good metabolic indicator for rumen development, differences were not observed between treatments in a particular week of age.

The effect of age on total protein concentration is due to variations over the weeks (Figure 2). Total protein concentration were lower, especially in the third week, reflecting the immunity window when the calf loses its maternal antibodies acquired from the colostrum intake and begins to develop its own immune system (Hulbert and Moisá, 2016). In contrast to the data obtained in this experiment, Morsy et al. (2016) reported that Brazilian red propolis increased total blood protein concentration $(P<0.01)$ of Santa Inês ewes supplemented $21 \mathrm{~d}$ before calving with $3 \mathrm{~g}$ of extract per ewe per day. The authors explained this increase through the ability of propolis to modulate protein metabolism. In the present study, the EEP did not present the capacity to modulate protein metabolism, evidenced by the drop in protein concentrations during the immunity window of the calves.

Transferrin is a blood protein that binds to iron and transports it. It may be measured indirectly so that its level is expressed as the amount of iron it is capable of binding. Iron-binding capacity decreased during the

Table 2. Fecal score, days with diarrhea, days with fever, and veterinary treatments of calves supplemented or not with red propolis extract

\begin{tabular}{|c|c|c|c|c|c|c|}
\hline \multirow[b]{2}{*}{ Item } & \multicolumn{2}{|c|}{ Treatment } & \multirow[b]{2}{*}{ SEM } & \multicolumn{3}{|c|}{$P$-value ${ }^{2}$} \\
\hline & Control & Propolis $^{1}$ & & $\mathrm{~T}$ & $\mathrm{~A}$ & $\mathrm{~T} \times \mathrm{A}$ \\
\hline Fecal score & 1.9 & 1.7 & 0.07 & 0.0229 & $<0.0001$ & 0.7579 \\
\hline Days with diarrhea & 1.7 & 1.0 & 0.19 & 0.0234 & $<0.0001$ & 0.2127 \\
\hline Days with fever & 0.4 & 0.2 & 0.09 & 0.2453 & 0.0128 & 0.3285 \\
\hline \multicolumn{7}{|c|}{ Veterinary treatments/calf } \\
\hline Diarrhea & 0.86 & 0.22 & 0.149 & 0.003 & - & - \\
\hline Pneumonia & 0.06 & 0.12 & 0.075 & 0.559 & - & - \\
\hline
\end{tabular}

${ }^{1}$ Propolis $=4 \mathrm{~mL} / \mathrm{d}$ of ethanolic extract of red propolis $(30 \%)$ fed with the liquid diet.

${ }^{2} \mathrm{~T}=$ treatment effect; $\mathrm{A}=$ age effect; $\mathrm{T} \times \mathrm{A}=$ treatment $\times$ age interaction. 

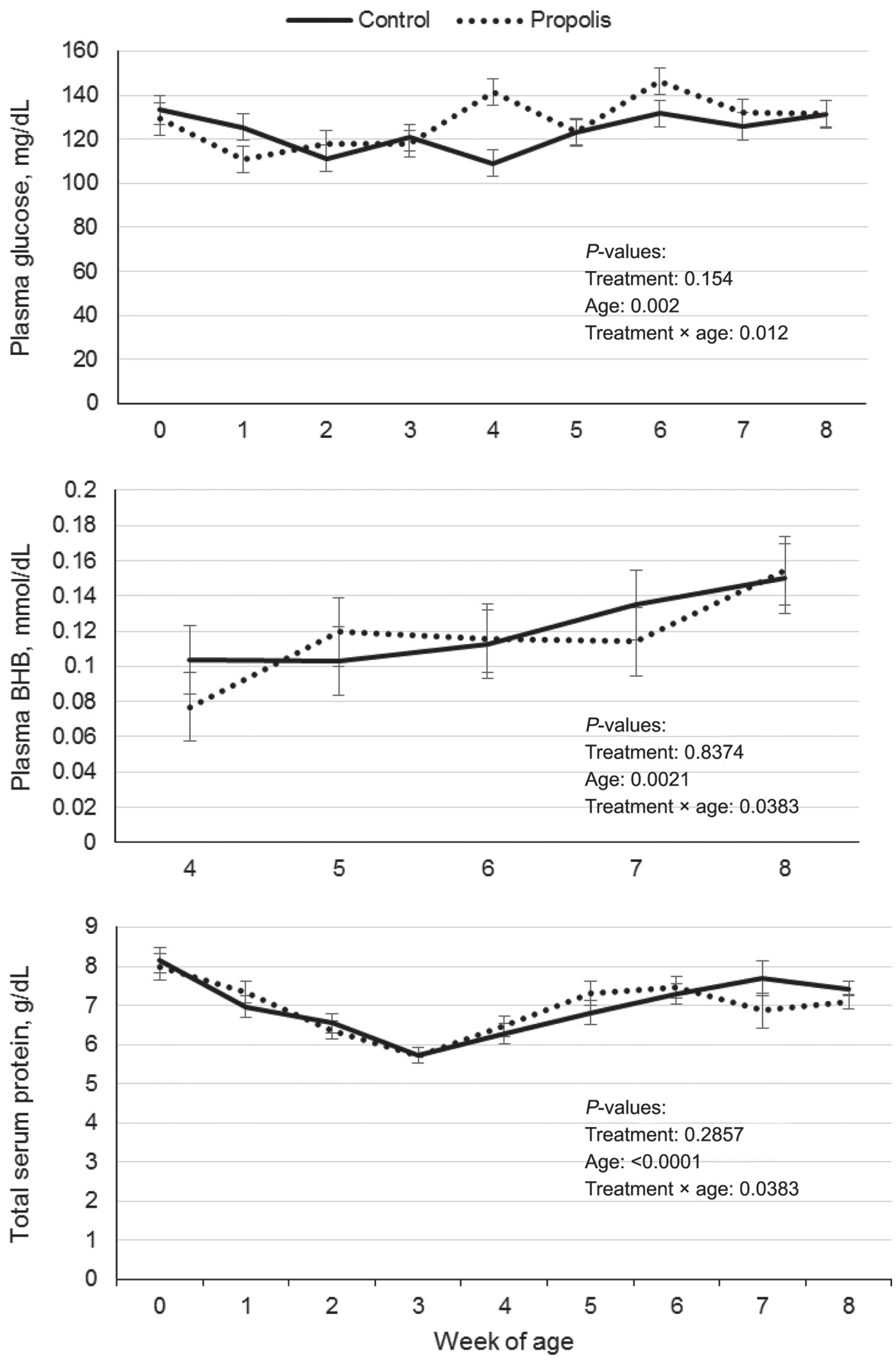

Figure 2. Plasma glucose $(\mathrm{mg} / \mathrm{dL})$, plasma BHB $(\mathrm{mmol} / \mathrm{dL})$, and total serum protein $(\mathrm{g} / \mathrm{dL})$ of calves supplemented or not with red propolis extract $[4 \mathrm{~mL} / \mathrm{d}$ of ethanolic extract of red propolis $(30 \%)$ fed with the liquid diet]. Error bars indicate SEM. 
Table 3. Blood parameters and erythrocyte and leukocyte counts of calves supplement or not with red propolis extract

\begin{tabular}{|c|c|c|c|c|c|c|}
\hline \multirow[b]{2}{*}{ Item } & \multicolumn{2}{|c|}{ Treatment } & \multirow[b]{2}{*}{ SEM } & \multicolumn{3}{|c|}{$P$-value ${ }^{2}$} \\
\hline & Control & Propolis $^{1}$ & & $\mathrm{~T}$ & A & $\mathrm{T} \times \mathrm{A}$ \\
\hline Glucose, mg/dL & 123.5 & 127.9 & 2.37 & 0.154 & 0.002 & 0.012 \\
\hline Total protein, g/dL & 7.0 & 6.9 & 0.15 & 0.2857 & $<0.0001$ & 0.195 \\
\hline Urea, mg/dL & 17.3 & 17.5 & 0.58 & 0.7499 & 0.0095 & 0.7119 \\
\hline Lactate, $\mathrm{mg} / \mathrm{dL}$ & 14.0 & 14.3 & 0.72 & 0.8129 & $<0.0001$ & 0.6974 \\
\hline $\mathrm{BHB}, \mathrm{mmol} / \mathrm{dL}$ & 0.12 & 0.12 & 0.017 & 0.8374 & 0.0021 & 0.0383 \\
\hline Iron-binding capacity, $\mu \mathrm{g} / \mathrm{dL}$ & 268.3 & 269.2 & 106.66 & 0.948 & $<0.0001$ & 0.482 \\
\hline Red blood cells, $\times 10^{6} / \mu \mathrm{L}$ & 7.0 & 6.3 & 0.26 & 0.043 & 0.0085 & 0.471 \\
\hline White blood cells, $\times 10^{3} / \mu \mathrm{L}$ & 8.9 & 8.2 & 0.46 & 0.313 & 0.0396 & 0.824 \\
\hline
\end{tabular}

${ }^{1}$ Propolis $=4 \mathrm{~mL} / \mathrm{d}$ of ethanolic extract of red propolis $(30 \%)$ fed with the liquid diet.

${ }^{2} \mathrm{~T}=$ treatment effect; $\mathrm{A}=$ age effect; $\mathrm{T} \times \mathrm{A}=$ treatment $\times$ age interaction.

milk-feeding period (Table 3). Iron concentration has a great effect on oxidative status, playing an important role in protecting the body against oxidative stress $(\mathrm{Ce}-$ ciliani, 2017). Because of the high antioxidant capacity found in red propolis, it was expected that animals supplemented with EEP would present greater rates of iron-binding capacity.

The EEP supplementation did not affect WBC count $(P>0.05)$. However, total RBC counts were greater in calves supplemented with EEP $(P=0.043)$. Both parameters were affected by animal age $(P<0.05$; Table $3)$. Overall, the total RBC counts of EEP-supplemented calves remained lower; however, the results found in the present study were within the values considered appropriate for healthy calves, from $7.54 \times 10^{6} / \mu \mathrm{L}$ to 6.11 $\times 10^{6} / \mu \mathrm{L}$ (Panousis et al., 2018). Prado-Calixto et al. (2017) in an experiment with sheep receiving diets with propolis-based additives showed no effect of propolis on hematological parameters (erythrocytes, hemoglobin, or hematocrit). Different from that, Kupczyński et al. (2012) reported an increase in the number of erythrocytes $(P<0.01)$ during the second week of life in calves receiving $4 \mathrm{~mL} / \mathrm{d}$ of $10 \%$ propolis extract. The authors also observed that the highest concentrations of iron occurred in animals supplemented with $4 \mathrm{~mL} / \mathrm{d}$ of propolis, concomitant with the trend in increasing red cell count in the same period. Thus, supplementation with EEP was not expected to decrease RBC counts due to its antioxidant capacity.

The WBC counts were also within the physiological ranges, and no differences were observed between groups (Table 3). However, the WBC counts were affected by age, with increasing numbers as animals aged because of immunity development. Sarker and Yang (2010) also observed no significant difference in WBC counts among feed-additive groups (propolis, antibiotics, and control) in postweaning calves. On the other hand, Morsy et al. (2016) reported an increase in WBC in Santa Inês ewes supplemented with red propolis $(P$ $<0.01)$. Because of the immunostimulatory activity of propolis, it was expected that EEP would affect immune parameters. Propolis can stimulate the immune system and increase the amount of leukocytes (Talas and Gulhan, 2009). Increasing the number of leukocytes may indicate an immune-stimulating effect of propolis (Nassar et al., 2012), which is justified by the presence of flavonoids. Even though the isoflavonoids were present in the propolis samples, they did not affected the total leukocyte count in the present study. Although our results are most compatible with no important effect on the total leukocyte count, EEP supplementation was beneficial in preventing diarrhea in calves, suggesting the need for more studies to understand the complex immunomodulation activity of propolis.

\section{CONCLUSIONS}

No positive effects on performance and selected blood parameters were observed. However, red propolis can be used as an additive to prevent diarrhea in dairy calves and, therefore, reduce the use of antibiotics in calf-rearing systems.

\section{ACKNOWLEDGMENTS}

The authors acknowledge the continued support received from the College of Agriculture "Luiz de Queiroz" (Piracicaba, SP, Brazil) and appreciate the technical help provided by coworkers. The authors express their appreciation for the financial support provided as a scholarship by the Coordination for the Improvement of Higher Education Personnel (CAPES, Brasília, Brazil). The authors express their appreciation for the financial support for publication $(2017 / 13601-3)$ provided by the São Paulo Research Foundation (Fapesp), Brazil. 


\section{REFERENCES}

Alencar, S. M., T. L. C. Oldoni, M. L. Castro, I. S. R. Cabral, C. M. Costa-Neto, A. Curyj, P. L. Rosalen, and M. Ikegaki. 2007. Chemical composition and biological activity of a new type of Brazilian propolis: Red propolis. J. Ethnopharmacol. 113:278-283. https:// doi.org/10.1016/j.jep.2007.06.005.

AOAC International. 2002. Official Methods of Analysis. 18th ed. AOAC Int., Gaithersburg, MD.

Bastos, E. M. A. F., M. Simone, D. M. Jorge, A. E. E. Soares, and M. Spivak. 2008. In vitro study of the antimicrobial activity of Brazilian propolis against Paenibacillus larvae. J. Invertebr. Pathol. 97:273-281. https://doi.org/10.1016/j.jip.2007.10.007.

Bittar, C. M. M., G. G. O. Napoles, C. E. Oltramari, J. T. Silva, M. R. De Paula, F. H. R. Santos, M. P. Gallo, and G. B. Mourão. 2016. Crude glycerin as a replacement for corn in starter feed: Performance and metabolism of pre-weaned dairy calves. Anim. Prod. Sci. 57:649-655. https://doi.org/10.1071/AN15451.

Bueno-Silva, B., D. Kawamoto, E. Ando-Suguimoto, R. C. V. Casarin, S. M. Alencar, P. L. Rosalen, and M. P. A. Mayer. 2017. Brazilian red propolis effects on peritoneal macrophage activity: Nitric oxide, cell viability, pro-inflammatory cytokines and gene expression. J. Ethnopharmacol. 207:100-107. https://doi.org/10.1016/j .jep.2017.06.015.

Busanello, M., R. S. Rossi, L. D. Cassoli, J. C. F. Pantoja, and P. F. Machado. 2017. Estimation of prevalence and incidence of subclinical mastitis in a large population of Brazilian dairy herds. J. Dairy Sci. 100:6545-6553.

Ceciliani, F. 2017. Anemia and oxidative stress in calves: An ironclad problem? Vet. Rec. 181:263-264. https://doi.org/10.1136/vr .j4024.

Constable, P. D. 2003. Use of antibiotics to prevent calf diarrhoea and septicemia. Bov. Pract. 37:137-142.

Cueto, A. P., S. H. Alves, M. Pilau, R. Weiblen, T. F. Kubiça, and L. T. Lovato. 2011. Atividade antiviral do extrato de própolis contra o calicivírus felino, adenovírus canino 2 e vírus da diarréia viral bovina. Cienc. Rural 41:1800-1806. https://doi.org/10.1590/S0103 $-84782011001000021$.

de Paula, M. R., C. E. Oltramari, J. T. Silva, M. P. C. Gallo, G. B. Mourão, and C. M. M. Bittar. 2017. Intensive liquid feeding of dairy calves with a medium crude protein milk replacer: Effects on performance, rumen, and blood parameters. J. Dairy Sci. 100:4448-4456. https://doi.org/10.3168/jds.2016-10859.

Deelen, S. M., T. L. Ollivett, and D. M. Haines. 2014. Evaluation of a Brix refractometer to estimate serum immunoglobulin $\mathrm{G}$ concentration in neonatal dairy calves. J. Dairy Sci. 97:3838-3844. https: //doi.org/10.3168/jds.2014-7939.

Ghisalberti, E. L. 1979. Propolis: A review. Bee World 60:59-84. https: //doi.org/10.1080/0005772X.1979.11097738.

Hulbert, L. E., and S. J. Moisá. 2016. Stress, immunity and the management of calves. J. Dairy Sci. 99:3199-3216. https://doi.org/10 $.3168 /$ jds. $2015-10198$.

Kadhim, M. J., A. Los, K. Olszewski, and G. Borsuk. 2018. Propolis in livestock nutrition. Entomol. Ornithol. Herpetol. 7:207. https:/ /doi.org/10.4172/2161-0983.1000207.

Kupczyński, R., M. Adamski, D. Falta, and A. Roman. 2012. The efficiency of propolis in post-colostral dairy calves. Arch. Tierzucht 55:315-332. https://doi.org/10.5194/aab-55-315-2012.

Larson, L. L., F. G. Owen, J. L. Albright, R. D. Appleman, R. C. Lamb, and L. D. Muller. 1977. Guidelines toward more uniformity in measuring and reporting calf experimental data. J. Dairy Sci. 60:989-991. https://doi.org/10.3168/jds.S0022-0302(77)83975-1.

Lefier, D., R. Grappin, and S. Pochet. 1996. Determination of fat, protein, and lactose in raw milk by fourier transform infrared spectroscopy and by analysis with a conventional filter-based milk analyzer. J. AOAC Int. 79:711-717.

Mohri, M., K. Sharifi, and S. Eidi. 2007. Hematology and serum biochemistry of Holstein dairy calves: Age related changes and comparison with blood composition in adults. Res. Vet. Sci. 83:30-39. https://doi.org/10.1016/j.rvsc.2006.10.017.
Morsy, A. S., Y. A. Soltan, S. M. A. Sallam, S. M. Alencar, and A. L. Abdalla. 2016. Impact of Brazilian red propolis extract on blood metabolites, milk production, and lamb performance of Santa Inês ewes. Trop. Anim. Health Prod. 48:1043-1050. https://doi.org/10 .1007/s11250-016-1054-1.

Mot, D., E. Tîrziu, and I. Nichita. 2014. Study of bactericidal properties of propolis. Lucr. Stiint. Zooteh. Biotehnol. 47:256-259.

Nassar, S. A., A. H. Mohamed, and H. Soufy. 2012. Immunostimulant effect of Egyptian propolis in rabbits. ScientificWorldJournal 2012:901516. https://doi.org/10.1100/2012/901516.

Naylor, J. M. 1999. Oral electrolyte therapy. Vet. Clin. North Am. Food Anim. Pract. 15:487-504. https://doi.org/10.1016/S0749 $-0720(15) 30160-2$

Orsi, R. O., J. M. Sforcin, V. L. M. Rall, S. R. C. Funari, L. Barbosa, and J. R. A. Fernandes. 2005. Susceptibility profile of Salmonella against the antibacterial activity of propolis produced in two regions of Brazil. J. Venom. Anim. Toxins Incl. Trop. Dis. 11:109 116. https://doi.org/10.1590/S1678-91992005000200003.

Panousis, N., N. Siachos, G. Kitkas, E. Kalaitzakis, M. Kritsepi-Konstantinou, and G. E. Valergakis. 2018. Hematology reference intervals for neonatal Holstein calves. Res. Vet. Sci. 118:1-10. https:// doi.org/10.1016/j.rvsc.2018.01.002.

Prado-Calixto, M. O. P., I. Y. Mizubuti, E. L. A. Ribeiro, E. S. Pereira, R. T. Silva, N. L. Corletto, E. L. T. Peixoto, L. N. Carvalho, A. K. Nihei, F. L. Massaro Juniot, L. D. F. Silva, and S. Galbeiro. 2017. Comportamento ingestivo e parâmetros sanguíneos em ovinos que receberam dietas contendo aditivos à base de extratos de própolis em pó. Arq. Bras. Med. Vet. Zootec. 69:381-390. https://doi.org/ 10.1590/1678-4162-9065.

R Core Team. 2015. R: A Language and Environment for Statistical Computing. R Found. Stat. Comput., Vienna, Austria.

Roy, J. H. B. 1980. Factors affecting susceptibility of calves to disease. J. Dairy Sci. 63:650-664.

Rufatto, L. C., D. A. Santos, F. Marinho, J. A. P. Henriques, M. R. Ely, and S. Moura. 2017. Red propolis: Chemical composition and pharmacological activity. Asian Pac. J. Trop. Biomed. 7:591-598. https://doi.org/10.1016/j.apjtb.2017.06.009.

Sarker, M. S. K., and C. J. Yang. 2010. Propolis and illite as feed additives on performance and blood profiles of post-weaning Hanwoo calves. J. Anim. Vet. Adv. 9:2704-2709. https://doi.org/10.3923 ?javaa.2010.2704.2709.

Sforcin, J. M., A. Fernandes, C. A. M. Lopes, V. Bankova, and S. R. C. Funari. 2000. Seasonal effect on Brazilian propolis antibacterial activity. J. Ethnopharmacol. 73:243-249. https://doi.org/10.1016/ S0378-8741(00)00320-2.

Silva, B. B., P. L. Rosale, J. A. Cury, M. Ikegaki, V. C. Souza, A. Esteves, and M. A. Severino. 2008. Chemical composition and botanical origin of red propolis, a new type of Brazilian propolis. Evid. Based Complement. Alternat. Med. 5:313-316. https://doi .org/10.1093/ecam/nem059.

Stradiotti, J. D., A. C. Queiroz, R. P. Lana, C. G. Pacheco, M. M. L. Camardelli, E. C. Eifert, P. M. M. Nunes, and M. V. M. Oliveira. 2004. Ação do extrato de própolis sobre a fermentação in vitro de diferentes alimentos pela técnica de produção de gases. Rev. Bras. Zootec. 33:1093-1099. https://doi.org/10.1590/S1516 -35982004000400030 .

Svensson, C., K. Lundborg, U. Emanuelson, and S. O. Olsson. 2003. Morbidity in Swedish dairy calves from birth to 90 days of age and individual calf-level risk factors infectious diseases. Prev. Vet. Med. 58:179-197. https://doi.org/10.1016/S0167-5877(03)00046-1.

Talas, Z. S., and M. F. Gulhan. 2009. Effects of various propolis concentrations on biochemical and hematological parameters of rainbow trout (Oncorhynchus mykiss). Ecotoxicol. Environ. Saf. 72:1994-1998. https://doi.org/10.1016/j.ecoenv.2009.04.011.

Teuber, M. 2001. Veterinary use and antibiotic resistance. Curr. Opin. Microbiol. 4:493-499. https://doi.org/10.1016/S1369 -5274(00)00241-1.

Tikosfsky, L. L., J. W. Barlow, C. Santisteban, and Y. H. Schukken. 2003. A comparison of antimicrobial susceptibility patterns for Staphylococcus aureus in organic and conventional dairy 
herds. Microb. Drug Resist. 9:39-45. https://doi.org/10.1089/ 107662903322541883

Timmerman, H. M., L. Mulder, H. Everts, D. C. van Espen, E. van der Wal, G. Klaassen, S. M. G. Rouwers, R. Hartemink, F. M. Rombouts, and A. C. Beynen. 2005. Health and growth of veal calves fed milk replacers with or without probiotics. J. Dairy Sci. 88:2154-2165. https://doi.org/10.3168/jds.S0022-0302(05)72891 -5 .

Ugur, A., M. Barlas, N. Ceyhan, and V. Turkmen. 2000. Antimicrobial effects of propolis extracts on Escherichia coli and Staphylococcus aureus strains resistant to various antibiotics and some microorganisms. J. Med. Food 3:173-180. https://doi.org/10.1089/jmf .2000.3.173.

Van Soest, P. J., J. B. Robertson, and B. A. Lewis. 1991. Methods for dietary fiber, neutral detergent fiber, and nonstarch polysaccharides in relation to animal nutrition. J. Dairy Sci. 74:3583-3597.

Wang, Z., and L. A. Goonewardene. 2004. The use of MIXED models in the analysis of animal experiments with repeated measures data. Can. J. Anim. Sci. 84:1-11. https://doi.org/10.4141/A03-123.

Weiss, W. P. 1993. Predicting energy values of feeds. In Symposium: Prevailing concepts in energy utilization by ruminants. J. Dairy Sci. 76:1802-1811.
Wiles, P. G., I. K. Gray, and R. C. Kissling. 1998. Routine analysis of protein by Kjeldahl and Dumas methods: Review and interlaboratory study using dairy products. J. AOAC Int. 81:620-632.

Yaghoubi, S. M., G. R. Ghorbani, H. R. Rahmani, and A. Nikkah. 2008. Growth, weaning performance and blood indicators of humoral immunity in Holstein calves fed supplemental flavonoids. J. Anim. Physiol. Anim. Nutr. (Berl.) 92:456-462. https://doi.org/10 $.1111 / j .1439-0396.2007 .00734 . x$.

Yucel, B., A. Onenc, A. Kaya, and O. Altan. 2015. Effects of propolis administration on growth performance and neonatal diarrhea of calves. SOJ Vet. Sci. 1:102. https://doi.org/10.15226/2381-2907/ $1 / 1 / 00102$.

Zawadzki, F., I. N. Prado, J. A. Marques, L. M. Zeoula, P. P. Rotta, B. B. Sestari, M. V. Valero, and D. C. Rivaroli. 2011. Sodium monensin or propolis extract in the diets of feedlot-finished bulls: Effects on animal performance and carcass characteristics. J. Anim. Feed Sci. 20:16-25. https://doi.org/10.22358/jafs/66153/2011. 